\title{
ER and PR signaling nodes during mammary gland development
}

\author{
Tamara Tanos 1,2, Lucia Jimenez Rojo,3, Pablo Echeverria ${ }^{4}$ and Cathrin Brisken*1
}

\begin{abstract}
The ovarian hormones estrogen and progesterone orchestrate postnatal mammary gland development and are implicated in breast cancer. Most of our understanding of the molecular mechanisms of estrogen receptor (ER) and progesterone receptor (PR) signaling stems from in vitro studies with hormone receptor-positive cell lines. They have shown that ER and PR regulate gene transcription either by binding to DNA response elements directly or via other transcription factors and recruiting co-regulators. In addition they cross-talk with other signaling pathways through nongenomic mechanisms. Mouse genetics combined with tissue recombination techniques have provided insights about the action of these two hormones in vivo. It has emerged that hormones act on a subset of mammary epithelial cells and relegate biological functions to paracrine factors. With regards to hormonal signaling in breast carcinomas, global gene expression analyses have led to the identification of gene expression signatures that are characteristic of ERa-positive tumors that have stipulated functional studies of hitherto poorly understood transcription factors. Here, we highlight what has been learned about ER and PR signaling nodes in these different systems and attempt to lay out in which way the insights may converge.
\end{abstract}

\section{Introduction}

The ovarian hormones estrogen and progesterone play pre-eminent roles in the female reproductive system and orchestrate postnatal mammary gland development in conjunction with pituitary hormones and other factors

*Correspondence: cathrin.brisken@epfl.ch

'Ecole polytechnique fédérale de Lausanne, ISREC - Swiss Institute for Experimental Cancer Research, NCCR Molecular Oncology, SV2832 Station 19, $\mathrm{CH}-1015$ Lausanne, Switzerland

Full list of author information is available at the end of the article
[1]. Both estrogen and progesterone can interact with membrane receptors [2,3]. Yet most of their known biological functions are mediated by their binding to and activation of the ligand-dependent transcription factors, estrogen receptor (ER) and progesterone receptor (PR).

$E R$ and $P R$ are members of the nuclear hormone receptor (HR) superfamily; they contain structurally conserved and functionally distinct domains that include a central DNA binding domain, a ligand binding domain close to the $\mathrm{COOH}$ terminus, variable $\mathrm{NH}_{2}$-terminal domains related to transcriptional activation/repression and the well-characterized transcriptional activation domains AF-1 and AF-2 [4]. Specifically, AF-1 is an $\mathrm{NH}_{2}-$ terminal ligand-independent transcriptional activator whereas AF-2 is a ligand-dependent activation domain located in the ligand binding domain, which regulates transcription by association with transcriptional coregulators [4-6]. There are two ERs (ER $\alpha$ and ER $\beta)$ encoded by distinct genes on different chromosomes and two known isoforms of PR (PRA and PRB) transcribed from the alternate usage of different promoters from the same gene [7].

The breast epithelium consists of basal cells, mostly myoepithelial, and luminal cells. ER $\alpha$ and PR are expressed in about $30 \%$ of the luminal cells [8], while basal cells do not express the HRs. Two-thirds of all breast cancers are ER-positive [9], which means that ER $\alpha$ expression is detectable by immunohistochemistry in more than $1 \%$ of the tumor cells [10]. HR status is a major biological parameter with important implications for prognosis and treatment. Interestingly, unsupervised clustering of global gene expression profiles of large sets of clinical breast cancer specimens reproducibly separates the tumors into ER-positive luminal tumors and ER-negative tumors [11,12].

\section{Molecular mechanisms involved in ERa and PR signaling}

In vitro studies, with the ER-positive breast cancer cell line MCF-7, have revealed that in their unliganded state $E R \alpha$ and PR are in complexes with heat shock proteins $[13,14]$. Upon hormone binding, the receptors dissociate from the heat shock proteins, dimerize and associate 
with DNA [15]. The receptors can bind to DNA directly or indirectly, by physically interacting with other transcription factors such as AP-1, SP-1, STAT3, or NF-kB [16-19]. Both ER and PR recruit coactivators and/or corepressors to elicit transcriptional changes [1]. In addition to these so-called genomic mechanisms, steroids activate rapid signaling events that involve the generation of second-messenger molecules, for instance cAMP, and activation of signal transduction pathways in the cytoplasm [20], known as nongenomic mechanisms.

\section{Coactivators/co-repressors regulate ER-dependent and PR-dependent gene expression}

Regulation of target gene expression by $17 \beta$-estradiol (E2) and progesterone is mediated by direct interaction of their nuclear receptors with co-regulatory proteins and components of the RNA polymerase II transcription initiation complex. Co-regulatory molecules can be functionally divided into coactivators and co-repressors (reviewed in [21]). Coactivators include SRC/p160 family members, E3 ubiquitin-protein ligases, p300/CBP and related proteins that possess enzymatic activities which modify histones to relax chromatin, thereby promoting transcription [22]. Specifically, SRC and p300/CBP have histone acetyltransferase activity, whilst the E6-associated protein that interacts with both ER and PR has ubiquitin ligase activity [23].

Co-repressors, such as N-CoR and SMRT, form complexes with deacetylases that modify histone tails, thereby stabilizing a more compact chromatin state. In addition, co-repressor complexes present high affinity for deacetylated histones, which further enhance the repression of ER and PR target genes [24].

Nuclear receptor phosphorylation has been related to recruitment of coactivators/co-repressors. Different signaling pathways can affect specific interactions; phosphorylation of ER $\alpha$ is necessary for interactions of the receptor with certain coactivators while it reduces interactions with co-repressors (reviewed in [25]). Interestingly, receptor binding to coactivator can induce allosteric changes in coactivators enhancing the recruitment of other coactivators, consequently increasing receptordependent transcription.

\section{ER and PR nongenomic mechanisms}

Nongenomic effects of ER/PR signaling include crosstalk with growth factor receptors and G-protein-coupled receptors in the cytosol (see Figure 1) within seconds to minutes after exposure to estrogens or progesterone. Ligand-bound receptors can initiate membrane proximal kinase cascades; for instance, ER $\alpha$ can activate Src-kinase leading to epidermal growth factor receptor (EGFR), mitogen-activated protein kinase (MAPK) and phosphatidylinositol-3-kinase signaling [26-31], whereas PR can trigger Src-MAPK and Akt signaling [32,33] (Figure 1).

At the same time, other signaling pathways impinge on ER and PR signaling by phosphorylating the receptors on multiple sites, thereby modulating their function $[34,35]$. In particular, Ser-118 phosphorylation is important for $\mathrm{ER} \alpha$ transcriptional activity [35]. ER is phosphorylated in Ser-188 by MAPKs after EGFR activation by epidermal growth factor [36] or after estrogen stimulation [37]. Other phosphorylation sites, such as Ser-305 and Thr-331, affect ER-coactivator interactions [38-40]. Besides, Thr-331 phosphorylation is required for nuclear localization and transcriptional activation of ER $\alpha$ [35]. Not only serines and threonines are phosphorylated in ER $\alpha$, but also tyrosine residues such as Tyr-537 that is a substrate for src family kinases and is required for the optimal ligand binding conformation of ER $\alpha$ [41]. Interestingly, a single signaling pathway can activate HRs by several mechanisms. For example, protein kinase A can directly phosphorylate and thereby activate ER $\alpha$ [39], or can act through CAMP to activate ER $\alpha$-mediated transcription [42]. In addition, protein kinase A phosphorylates the coactivator-associated arginine methyltransferase-1, allowing it to interact with the ER $\alpha$. This interaction, in turn is necessary for CAMP activation of ER $\alpha$ [43] (Figure 1).

In the case of PR, the best-characterized phosphorylation sites are Ser-294, Ser-345 and Ser-400. Ser-294 phosphorylation is important for PR nuclear translocation, ligand-dependent PR transactivation and the half-life of the receptor as Ser-294 phosphorylation targets the receptor for ubiquitination [44]. A particularly interesting example of the complex crosstalk with tyrosine kinase receptor-driven signaling is the interaction between PR and EGFR; progestins can activate EGFR, resulting in activation of $\mathrm{c}-\mathrm{Src}$ and the downstream MAPK. This activation, in turn, leads to PR phosphorylation on Ser-345 and activation of transcription [45]. Besides, PR phosphorylation on Ser-294 has been implicated in PR ligand-independent activation of Src, and consequently Stat-3, resulting in increased proliferation of tumor cell lines [46]. Phosphorylation on Ser-400 modulates ligand-independent transcriptional activities of PR. Cyclin-dependent kinase 2 can phosphorylate on PR Ser-400 in the absence of progestins and is required for PR nuclear translocation in the absence of ligand [47].

HRs can hence be activated in a ligand-independent fashion by multiple kinase cascades [48-51]. Nongenomic estrogen effects predominantly involve classical ERs residing in cytoplasm and at the cell membrane, where $E R \alpha$ can be found in direct association with palmitic acid [52]. However, other membrane receptors for estrogens and progesterone acting through nongenomic mechanisms have been described and are reviewed elsewhere [53]. 


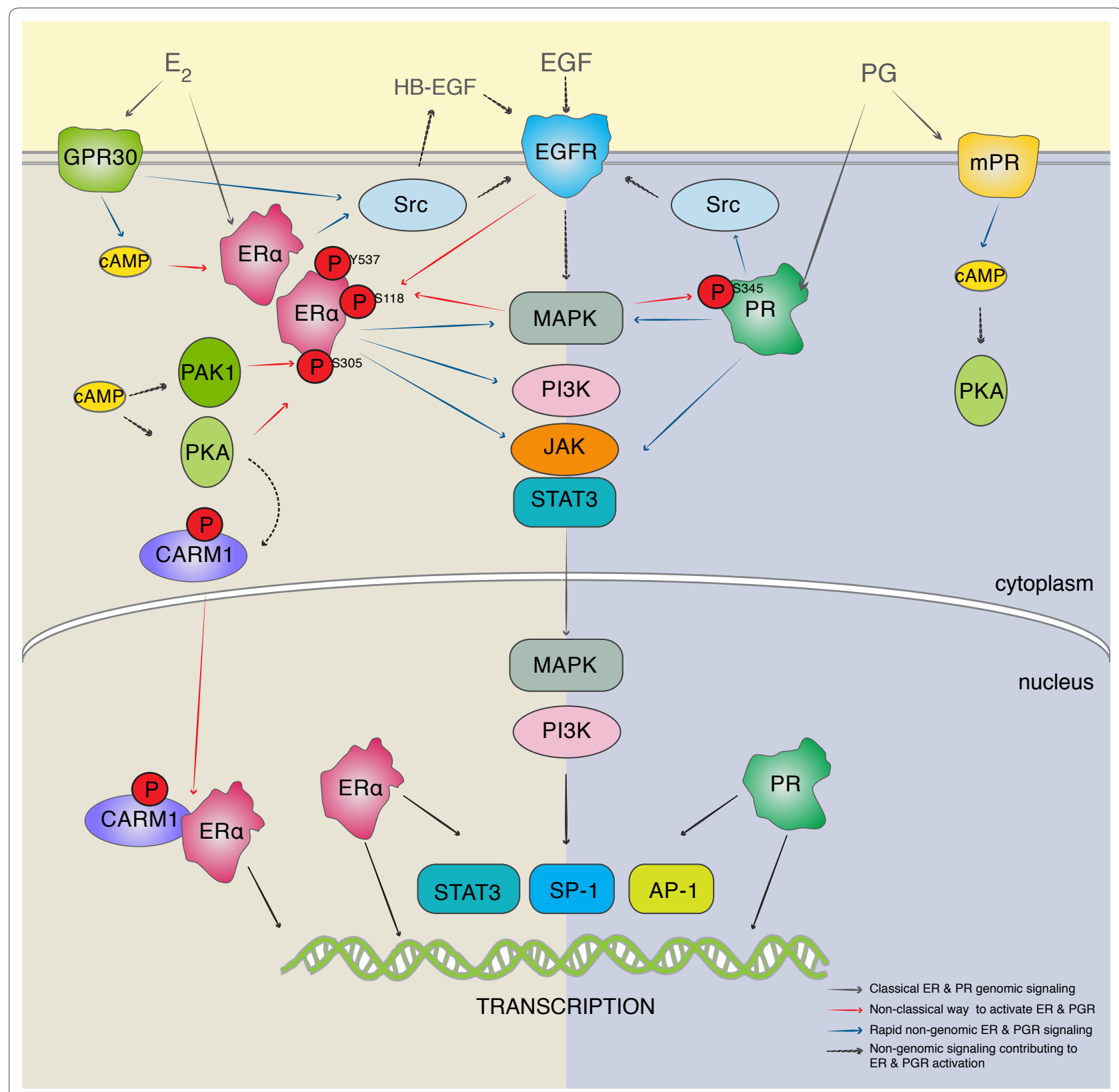

Figure 1. Integration of genomic and nongenomic estrogen receptor and progesterone receptor signaling pathways. Estrogen receptor (ER) and progesterone receptor (PR) can bind directly to DNA-specific sequences or indirectly by binding to other transcription factors. In addition, ERa and PR are able to activate several signaling pathways (mitogen-activated protein kinases (MAPKs), JAK/STAT, SRC or phosphatidylinositol-3kinase (PI3K)) (blue arrows). In parallel, epidermal growth factor receptor (EGFR) activation by epidermal growth factor (EGF) or mediated by ERa activates MAPKs, which in turn can phosphorylate and probably activate ERa or PR. Protein kinase A (PKA) and PAK phosphorylate and activate ERa (red arrows). CAMP is involved in the activation of both ERa and PR receptors and can be induced by membrane receptors such as GPR30 or mPR. Besides, coactivators can participate in ERa activation by crosstalk with other signaling pathways; the coactivator coactivator-associated arginine methyltransferase-1 (CARM1) activates ERa by CAMP signaling, leading to ERa phosphorylation. Once phosphorylated, ER and CARM1 interact and can bind to the DNA to regulate target genes. E2, 17ß-estradiol; HB, heparin-binding; PG, progesterone.

With all ER and PR signaling converging on transcriptional regulation, the identification of target genes has long been of interest. Various global gene expression profiling studies identified between 100 and 500
E2-responsive genes (reviewed in [54]) and multiple PR targets [55-57]. More recently, large-scale detection of ER binding sites by chromatin immunoprecipitation (ChIP), initially combined with tiling arrays and more recently 
with deep sequencing, have established genome-wide maps (reviewed in [58]). These studies revealed more than 5,000 ER binding sites, of which only 4\% were located in promoter regions. Most binding occurs at distant regulatory elements, suggesting very complex mechanisms of transcriptional regulation [59].

\section{ERa and PR signaling in the mammary gland}

Estrogens and progesterone play prominent roles in driving and coordinating postnatal mammary gland development. The mouse mammary gland offers unique experimental opportunities to genetically dissect signaling pathways involved in the development of this organ. In 3-week-old females, the inguinal gland can be cleared of its endogenous epithelium; any piece of mammary epithelium can then be engrafted into such a cleared fat pad and will grow out and recapitulate development [60]. Comparison of HR-deficient and wild-type epithelia engrafted into contralateral cleared fat pads discerned that estrogens trigger expansion of the rudimentary ductal system into the mammary fat pad during puberty acting via epithelial ER $\alpha$ [61], whereas the epithelial PR is required in adulthood during estrous cycles and pregnancy to bring about side branching, thereby enhancing the complexity of the ductal system [1]. When divested fat pads were reconstituted with $\mathrm{ER}^{-/-}$or $\mathrm{PR}^{-/-}$ epithelial cells mixed with wild-type cells the former contributed to all aspects of mammary gland development, establishing that the two hormones can act by paracrine mechanisms [61,62]. HR-positive cells have thus emerged as sensor cells that act as mediators translating the systemic signals into local commands, thereby amplifying and prolonging the initial stimulus and coordinating the behavior of multiple cell types [63]. Interestingly, HR-positive cells proliferate less than HRnegative cells $[64,65]$. This has been attributed to negative regulation by transforming growth factor beta-1, which is specifically activated in the extracellular matrix of ER $\alpha$ positive cells [66].

\section{Paracrine mediators of estrogen function during puberty}

$E R \alpha$ signaling is activated when estrogens are secreted by the ovaries with puberty. The EGFR ligand, amphiregulin (AREG), is the only EGFR ligand induced by estrogens in the pubertal mouse mammary gland and is an essential paracrine mediator of estrogen-induced proliferation that drives ductal elongation $[67,68]$ (Figure 2). AREG is a membrane-anchored protein and needs to be cleaved to be active $[69,70]$. The metalloproteinase ADAM17 (TNF $\alpha-$ converting enzyme) is essential for this activation, as illustrated by studies showing that ADAM17 ${ }^{-1-}$ epithelium, like $\mathrm{ER}^{-1-}$ and $\mathrm{AREG}^{-/-}$epithelia, fails to grow out in a cleared fat pad but can be rescued by exogenous AREG [70].
Surprisingly, tissue recombination experiments revealed that AREG's cognate receptor, the EGFR, is not important in the mammary epithelium but is required in the mammary stroma [70-72]. Consistent with AREG produced by epithelial cells signaling to the stroma, stromal EGFR phosphorylation is decreased in the absence of epithelial ADAM17 [70]. There are several candidates that may signal back from the stroma to ultimately trigger epithelial cell proliferation, foremost being insulin-like growth factor-1 (Figure 2). Expression of insulin-like growth factor-1 mRNA is restricted to the stromal compartment and can induce ductal elongation $[73,74]$. Insulin-like growth factor-1 expression is also induced by estrogens in the mammary stroma of ovariectomized heifers [75], suggesting that this pathway is important and conserved across species.

Further attractive candidate mediators of stromalepithelial crosstalk in response to AREG-EGFR signaling are members of the fibroblast growth factor (FGF) family. FGFs are required for the branching morphogenesis in several organs including the lungs and salivary glands $[76,77]$. Specifically, FGF2 and FGF7 elicit branching of mammary organoids in three-dimensional matrigel cultures even in the absence of EGFR signaling [70], and in vivo stromal FGF7 expression is induced upon E2 stimulation [78]. Deletion of the cognate FGF receptor $2 b$ in mammary epithelial cells results in delayed ductal growth during puberty. Remarkably, in mosaic FGF receptor $2 \mathrm{~b}$ mutant epithelia the highly proliferative ductal tips consist almost exclusively of wild-type cells. This indicates that FGF receptor $2 \mathrm{~b}$ is required for epithelial cell proliferation [79], which may be elicited by FGFs released from stromal cells in response to EGFR activation by AREG (Figure 2). Importantly, around the proliferative ductal tips the basal lamina that typically separates epithelial and stromal compartments is thinned out or absent, a circumstance that facilitates interactions between epithelial and stromal cells.

Global gene expression profiling of mammary stroma after estrogen stimulation has revealed additional candidates that may signal back to the epithelium, such as a transforming growth factor beta extracellular inhibitor protein CAP-GLY domain containing linker protein 1, and thrombospondin 2 [80].

\section{Paracrine mediators of progesterone receptor signaling function in the adult mammary gland}

Wnt4 and receptor activator of NF-kB ligand (RANKL) have been implicated as important paracrine mediators of progesterone function (Figure 2). Wnt4 is a secreted protein that belongs to the Wnt signaling pathway, involved in many developmental processes. Epithelial outgrowths derived from Wnt4-/- or wild-type mammary buds transplanted in contralateral cleared fat pads 


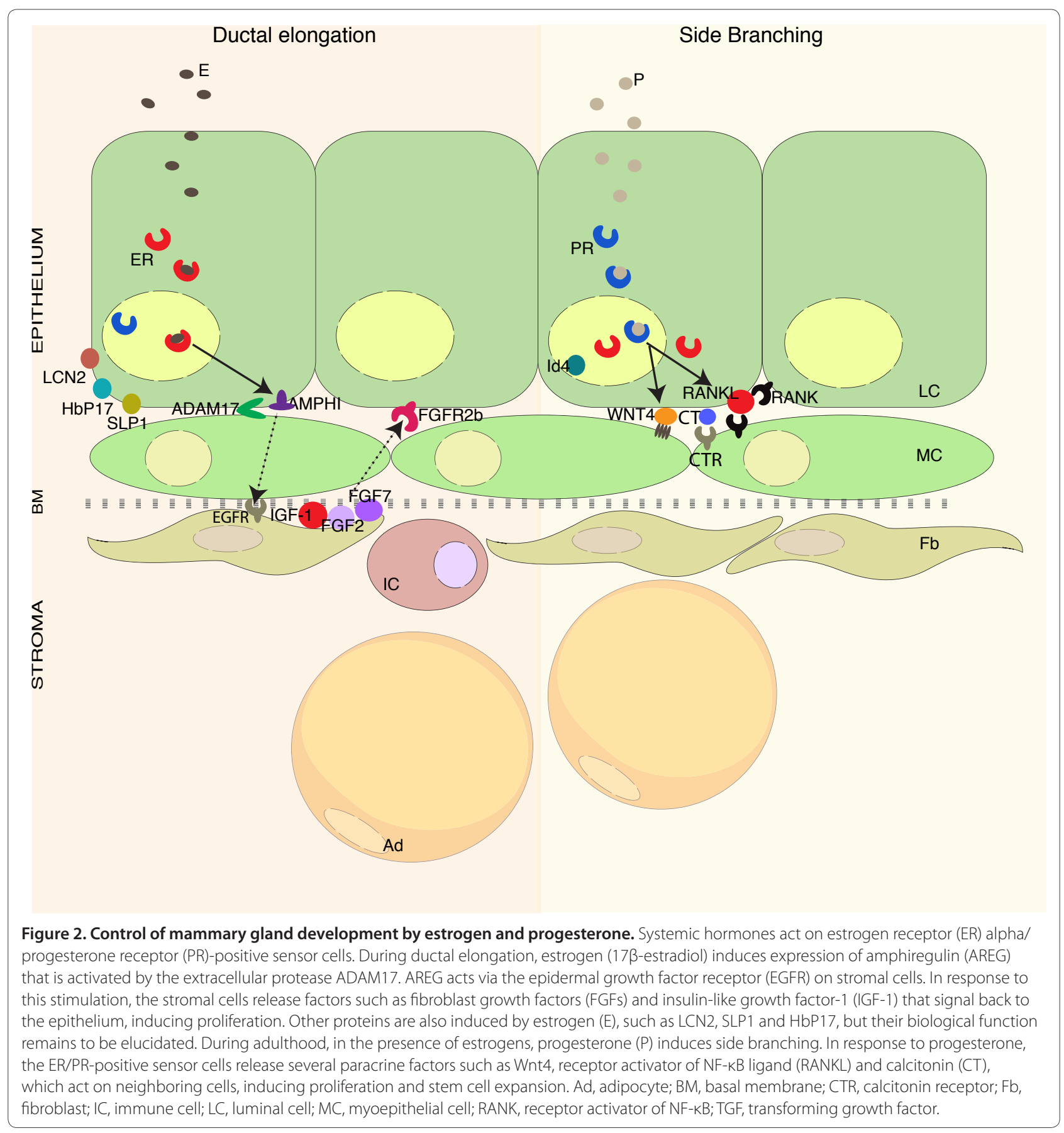

revealed that Wnt4 is required for side branching [81]. Wnt4 mRNA expression is induced by progesterone, and depends on intact epithelial PR signaling. In situ hybridization studies revealed that the spatial distribution of Wnt- 4 and PR mRNA are overlapping, suggesting that Wnt4 is expressed in PR-positive cells [81].

RANKL is a TNF family member that activates NF- $k B$ [82] and plays a fundamental role in antigen-presenting cells and during osteoclastogenesis [83]. The observation that RANKL-deficient females fail to lactate first pointed to a role of this factor in the mammary gland [84]. RANKL mRNA expression is induced in ovariectomized mice stimulated with progesterone [85], and depends on intact PR signaling as PRB-deficient mammary glands show decreased RANKL expression [86]. RANKL protein is exclusively expressed in PR-positive cells in the mammary epithelium $[65,86]$.

Ectopic expression of RANKL or its receptor (receptor activator of NF- $\mathrm{kB}$ ) in the mammary epithelium is sufficient to induce side branching in virgin mammary 
glands [87], and RANKL ${ }^{-/-}$mammary epithelia lack side branches and alveoli [65]. RANKL is necessary for the extensive proliferation of HR-negative epithelial cells in response to progesterone stimulation [65]. Transgenic RANKL expression in ER-positive mammary epithelial cells of PR-deficient females rescued the phenotype of PR knockout, unequivocally demonstrating that RANKL is an essential mediator of progesterone signaling [88].

Another paracrine mediator of PR signaling is calcitonin (Figure 2), a 32-amino-acid peptide hormone involved in calcium homeostasis [89]. Calcitonin expression is induced by progesterone in the luminal cells [90]. The cognate calcitonin receptor is expressed in the myoepithelium, suggesting that calcitonin may act as a paracrine factor in a heterotypic interaction; its biological function remains to be defined [90].

Taken together ER and PR nodes in the mammary gland involve paracrine signaling loops, with a strong involvement of the stroma in the case of pubertal ER signaling and possibly more crosstalk with myoepithelial cells in PR-driven epithelial proliferation.

\section{ER, PR and mammary stem cells}

Mammary stem cells have been defined as cells with the ability to reconstitute cleared fat pads and were shown to be enriched in a basal cell population characterized by a cell surface antigen profile consisting of low levels of the glycosyl phosphatidylinositol-anchored protein CD24 and high expression levels of $\beta_{1}$-integrin (CD29) and $\alpha_{6}$ integrin $(\mathrm{CD} 49)\left(\mathrm{CD} 24^{+} \mathrm{CD} 29^{\text {high }} \mathrm{CD} 49^{\text {high }}\right)[91,92]$. As these cells do not express HRs [93], it has been proposed that they are activated by hormones through paracrine signaling $[63,94]$. Elegant fluorescence-activated cell sorting experiments revealed that the size of the stem-cellenriched population depends on the hormonal status of the animal, increasing during diestrous and pregnancy and decreasing with ovariectomy and antiestrogen treatments $[95,96]$. RANKL has been proposed to act as a paracrine mediator of stem cell activation because expression of its cognate receptor, RANK, is enriched in the basal compartment $[95,96]$. However, recent lineage tracing experiments indicate that luminally and basally restricted stem cells coexist in the postnatal mammary gland [97]; hence a factor that activates luminal stem cells remains to be ascertained.

\section{Clues about hormone receptor function from studies on breast cancer samples}

Global gene expression profiling studies on large sets of breast cancer samples have consistently revealed five different breast tumor subtypes (luminal A, luminal B, HER2-enriched, claudin-low, basal-like) [98]. Luminal A and luminal B profiles represent ER-positive tumors. Comparison of different luminal/ER-specific signatures reveals major discrepancies and a limited number of genes that are repeatedly associated with the ER signature [11,99-106] (Table 1). These genes include Xbox binding protein 1 transcription factor, the LIV-1 subfamily of ZIP zinc transporter 9/solute carrier family 39 member 6 , solute carrier family 1 member 4 , solute carrier family 1 member 2 , trefoil factor 1 , trefoil factor 3, c-Myb, runt-related transcription factor 1, B-cell CLL/lymphoma 2 and stanniocalcin 2. Due to the heterogeneity in cellular composition of different tumors, the view is widely held that signature genes are highly expressed in the most abundant cell type within a given tumor - hence in the case of luminal tumors they are not necessarily related to ER function. Yet the strong correlation between GATA-3, forkhead box protein A1 (FOXA1) and ER $\alpha$ stipulated functional studies, which have revealed connections between these transcription factors and ER $\alpha$ function in the mammary gland and in mammary tumor models.

GATA-3 was shown to be expressed in the luminal cells of the normal mouse mammary gland and to be required to maintain luminal epithelial differentiation $[107,108]$. Loss of GATA-3 resulted in a decreased number of ER $\alpha-$ expressing cells [108], suggesting that GATA-3 is upstream of ER $\alpha$. In cell lines, however, estrogen stimulation results in an increase of GATA-3 transcripts, indicating that GATA-3 itself may be regulated by ER $\alpha$ [109]. Furthermore, ER $\alpha$ binds to the GATA-3 gene in ChIP assays [110-113]. Accordingly, it has been postulated that GATA-3 and ER $\alpha$ are involved in a positive cross-regulatory loop, with each of them required for the transcription of the other [109]. In the MMTV-PyMT mammary tumor model, GATA-3 loss marks progression from adenoma to early carcinoma and the onset of tumor spreading [114]. Clinically, GATA-3 expression shows inverse association with histological grade and human epidermal growth factor receptor 2 expression [107] and has been validated as a predictor for response to hormonal therapy in ER $\alpha$-positive tumors [115,116].

FOXA1 is also important for mammary gland development $[11,102,117]$. Like GATA-3 or ER $\alpha$ loss, FOXA1 deletion from the mammary epithelium leads to impaired pubertal ductal morphogenesis [118]. ER $\alpha$ expression is undetectable in tissue recombinants with $\mathrm{FOXA1}^{-/-}$ epithelium engrafted under the kidney capsule, suggesting that FOXA1 is necessary for ER $\alpha$ expression [118]. Besides, FOXA1 and ER $\alpha$ interact in the yeast two-hybrid system [119] and between 7 and 48\% of genes recruiting ER have been suggested to also bind FOXA1 in MCF-7 cells $[110,120]$, whereas FOXA1 enhances the interaction between ER and chromatin [121-123]. FOXA1 expression in ER-positive tumors correlates with a good prognosis [124], and is inversely associated with tumor size, histological grade, lymph vascular invasion, lymph node stage 


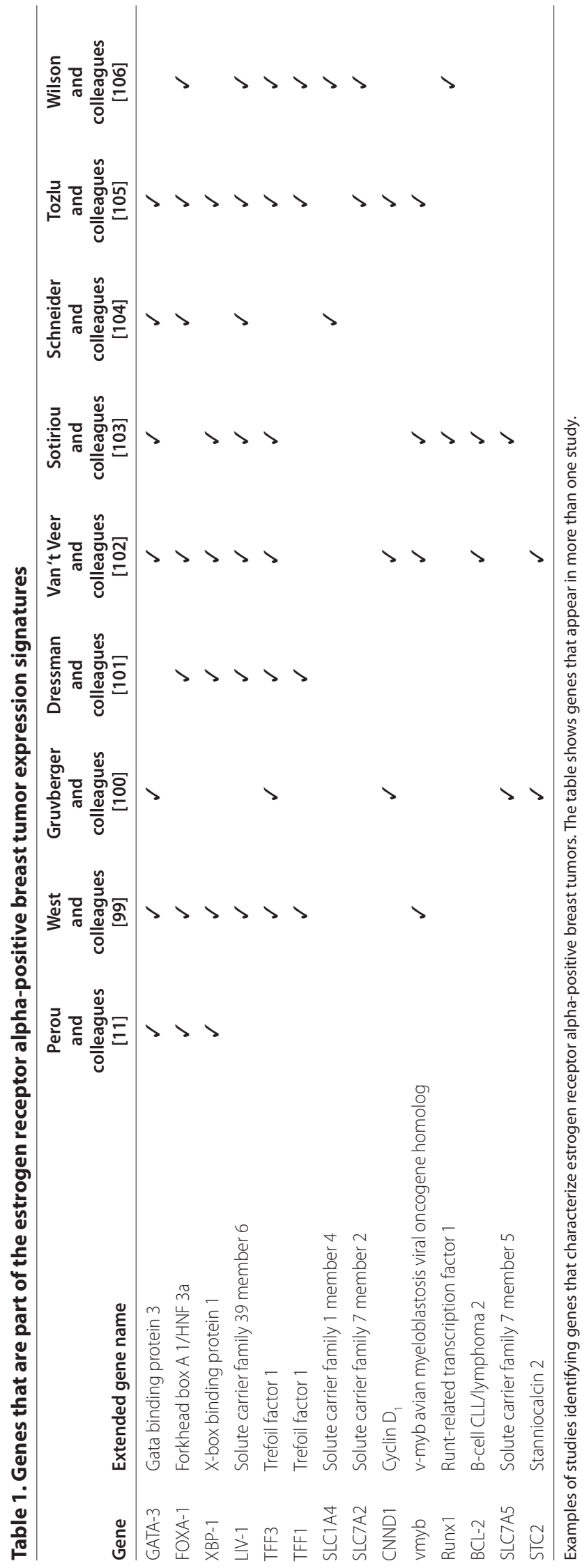

and human epidermal growth factor receptor 2 overexpression [125].

FOXA1 and GATA-3 are also related to each other; ectopic expression of GATA-3 induces FOXA1 mRNA [126] and GATA-3 binds to FOXA1 promoter in ChIP assays in MCF-7 cells [107] and in the normal mammary gland [107], suggesting that FOXA1 is a GATA-3 target gene.

Cyclin $D_{1}$ is linked in multiple ways to ER/PR function. In the mouse mammary gland, cyclin $\mathrm{D}_{1}$ was shown to be required for proliferation of HR-positive cells in response to progesterone [65]. Amplification and overexpression occurs almost exclusively in ER-positive tumors [127]; cyclin $\mathrm{D}_{1}$ and $\mathrm{ER} \alpha$ are frequently coexpressed in ductal hyperplasias and in breast carcinomas $[128,129]$. Within ER-positive tumors, cyclin $\mathrm{D}_{1}$ amplification identifies a group of women with poor prognosis [130].

Trefoil factor 1 and trefoil factor 3 may be of functional importance as their overexpression accelerates tumorigenesis in xenografted MCF-7 and T47D cells [131,132].

Interestingly, when T47D and MCF-7 cells are exposed to E2, the expression profiles between both cell lines shared several regulated genes and are similar, and some of them overlap with genes expressed in ER $\alpha$-positive tumors [133]. Furthermore, similar studies have shown that several of the ER $\alpha$ signature genes are upmodulated upon E2 stimulation in breast cancer ER $\alpha$-positive cell lines, with estrogen-responsive genes including GATA-3, FOXA-1, cyclin $\mathrm{D}_{1}$, trefoil factor 1 , X-box binding protein 1, LIV-1, stanniocalcin 2, B-cell CLL/lymphoma 2, and Myb [111,134-140]. Interestingly, several genes identified as E2-regulated genes in MCF-7 cells (such as cyclin $\mathrm{D}_{1}$ and GATA-3) [141] are present in tumor-defined luminal/ER gene clusters and help to predict outcome in response to tamoxifen treatment [141].

Global mapping of ER $\alpha$ binding sites through ChIP-seq has revealed sites in FOXA1 [111,113], GATA-3 $[111,113]$, CCND1 [111,142] and Runt-related transcription factor 1 [103]. Interestingly, ER $\alpha$ also binds to AREG [110], which is an important mediator of ER function in pubertal mammary gland development and is regulated by E2 in breast cancer cell lines [133]. AREG is not part of the luminal signatures but nevertheless may still have a role in breast tumors, possibly early in breast carcinogenesis when paracrine control mechanisms are still intact that might be lost later during tumor progression.

Global ER-binding events were mapped recently for the first time in tumor samples [143]. Excitingly, this study revealed signatures that predict clinical outcome.

\section{PR-associated nodes in breast cancer}

In most cases, PR-positive tumors also express ER and are studied within the ER-positive tumor group. Based on global gene expression studies on T47D and primary 
human bronchial epithelial cells [144], expression of RANKL and Wnt4 is not regulated by progesterone [55-57], yet PR has been shown to bind to the Wnt4 promoter by ChIP assay in T47D cells [145].

Clinically, 27\% of primary tumors express receptor activator of NF- $\mathrm{kB}$ [146]. RANKL expression was found in $11 \%$ of human invasive breast carcinoma [147], suggesting that the pathway may be active. Similarly, a role for Wnt signaling in breast cancer is suggested by the finding that extracellular inhibitors of the pathway such as secreted frizzled-related proteins, Dickkopf-3, Wntinhibitory factor- 1 and the intracellular antagonist of $\beta$ catenin, adenomatous polyposis coli, are epigenetically silenced in breast tumors [148-154]. Hence, these paracrine factors and the signaling they elicit may have a role in breast carcinogenesis.

\section{Conclusions}

HR-positive cells in the mammary gland act as sensor cells; they detect the systemic requirements reflected in hormone levels and translate them into local commands. The molecular underpinnings of this switching station are ER $\alpha$ and PR and their signaling nodes. Mouse genetics have established that in vivo paracrine signaling is of central importance to coordinate the behavior of luminal and stromal cells (ER) during puberty and of luminal and myoepithelial cells (PR) in the adult mammary gland. In vitro experiments with ER-positive breast cancer cell lines have revealed that these receptorsignaling nodes coordinate the actions of distantly acting endocrine signals with locally acting receptor tyrosine kinase and G-protein-coupled receptor ligands that ultimately modulate transcription. At least for ER we now know that the vast majority of its genomic action occurs through distant control elements.

Despite the limited overlap between the nodes emerging from the distinct approaches in breast cancer cell lines, during mammary gland development and in breast tumors, the EGFR pathway appears tightly linked to ER $\alpha$ and PR signaling at different levels. There is continuous crosstalk between EGFR and HRs [155] by nongenomic mechanisms, and in vivo the EGFR ligand AREG is an important paracrine mediator of estrogen action. AREG is also implicated early in breast carcinogenesis, as it was the most upregulated gene in a comparison between hyperplastic enlarged lobular units and normal terminal duct lobular units [156].

A major challenge remains to integrate the information acquired from the different approaches. Whether the intracellular signaling cascades triggered by hormones in cell lines work similarly in vivo remains to be determined. Increasingly sophisticated fluorescence-activated cell sorting-based cell separation approaches, laser capture dissection as well as in vivo signaling/imaging approaches should help to connect the currently separated views of $\mathrm{ER} \alpha / \mathrm{PR}$ signaling, taking into account that they operate only in a minor subset of cells in vivo.

\section{Abbreviations}

AREG, amphiregulin; ChIP, chromatin immunoprecipitation; E2, 17ß-estradiol; EGFR, epidermal growth factor receptor; ER, estrogen receptor; FGF, fibroblast growth factor; FOXA1, forkhead box protein A1; HR, hormone receptor; MAPK, mitogen-activated protein kinase; MMTV-PyMT, mouse mammary tumor virus, polyoma middle T; NF, nuclear factor; PR, progesterone receptor; RANKL, receptor activator of NF-KB ligand; TNF, tumor necrosis factor.

\section{Competing interests}

The authors declare that they have no competing interests.

\section{Acknowledgments}

This work was supported by NCCR Molecular Oncology, SNF (SNF grant 31003A). TT was the recipient of a Marie Curie Incoming international fellowship and LJR received a fellowship from the Government of the Basque Country.

\section{Author details}

'Ecole polytechnique fédérale de Lausanne, ISREC - Swiss Institute for Experimental Cancer Research, NCCR Molecular Oncology, SV2832 Station 19, $\mathrm{CH}-1015$ Lausanne, Switzerland. ${ }^{2}$ Roche Diagnosis GmbH, Oncology, Penzberg, Germany. ${ }^{3}$ nnstitute of Oral Biology, Zentrum für Zahnmedizin, Faculty of

Medicine, University of Zurich, Zurich, Switzerland. ${ }^{4}$ Département de Biologie Cellulaire, Université de Genève, Sciences III, 30 Quai Ernest-Ansermet, CH-

1211 Genève 4, Switzerland.

Published: 19 July 2012

\section{References}

1. Brisken C, O'Malley B: Hormone action in the mammary gland. Cold Spring Harb Perspect Biol 2010, 2:a003178.

2. Carmeci C, Thompson DA, Ring HZ, Francke U, Weigel RJ: Identification of a gene (GPR30) with homology to the G-protein-coupled receptor superfamily associated with estrogen receptor expression in breast cancer. Genomics 1997, 45:607-617.

3. Zhu Y, Rice CD, Pang Y, Pace $M$, Thomas P: Cloning, expression, and characterization of a membrane progestin receptor and evidence it is an intermediary in meiotic maturation of fish oocytes. Proc Natl Acad Sci US A 2003, 100:2231-2236.

4. McKenna NJ, O'Malley BW: Combinatorial control of gene expression by nuclear receptors and coregulators. Cell 2002, 108:465-474.

5. Edwards DP: The role of coactivators and corepressors in the biology and mechanism of action of steroid hormone receptors. J Mammary Gland Biol Neoplasia 2000, 5:307-324

6. Ellmann S, Sticht H, Thiel F, Beckmann MW, Strick R, Strissel PL: Estrogen and progesterone receptors: from molecular structures to clinical targets. Cell Mol Life Sci 2009, 66:2405-2426.

7. Kastner P, Krust A, Turcotte B, Stropp U, Tora L, Gronemeyer H, Chambon P. Two distinct estrogen-regulated promoters generate transcripts encoding the two functionally different human progesterone receptor forms $\mathrm{A}$ and B. EMBO J 1990, 9:1603-1614.

8. Clarke RB, Howell A, Potten CS, Anderson E: Dissociation between steroid receptor expression and cell proliferation in the human breast. Cancer Res 1997, 57:4987-4991.

9. Herynk MH, Fuqua SA: Estrogen receptor mutations in human disease. Endocr Rev 2004, 25:869-898.

10. Goldhirsch A, Ingle JN, Gelber RD, Coates AS, Thurlimann B, Senn HJ: Thresholds for therapies: highlights of the St Gallen International Expert Consensus on the primary therapy of early breast cancer 2009. Ann Oncol 2009, 20:1319-1329.

11. Perou CM, Sorlie T, Eisen MB, van de Rijn M, Jeffrey SS, Rees CA, Pollack JR, Ross DT, Johnsen H, Akslen LA, Fluge O, Pergamenschikov A, Williams C, Zhu SX, Lønning PE, Børresen-Dale AL, Brown PO, Botstein D: Molecular portraits of human breast tumours. Nature 2000, 406:747-752.

12. Sorlie T, Perou CM, Tibshirani R, Aas T, Geisler S, Johnsen H, Hastie T, Eisen MB, van de Rijn M, Jeffrey SS, Thorsen T, Quist H, Matese JC, Brown PO, Botstein D, 
Lønning PE, Børresen-Dale AL: Gene expression patterns of breast carcinomas distinguish tumor subclasses with clinical implications. Proc Natl Acad Sci U S A 2001, 98:10869-10874.

13. Catelli MG, Binart N, Jung-Testas I, Renoir JM, Baulieu EE, Feramisco JR, Welch WJ: The common 90-kd protein component of non-transformed ' $8 S^{\prime}$ steroid receptors is a heat-shock protein. EMBO J 1985, 4:3131-3135.

14. Echeverria PC, Picard D: Molecular chaperones, essential partners of steroid hormone receptors for activity and mobility. Biochim Biophys Acta 2010, 1803:641-649.

15. Falkenstein E, Tillmann HC, Christ M, Feuring M, Wehling M: Multiple actions of steroid hormones - a focus on rapid, nongenomic effects. Pharmacol Rev 2000, 52:513-556.

16. Petz LN, Ziegler YS, Loven MA, Nardulli AM: Estrogen receptor alpha and activating protein-1 mediate estrogen responsiveness of the progesterone receptor gene in MCF-7 breast cancer cells. Endocrinology 2002, 143:4583-4591.

17. Jeffy BD, Hockings JK, Kemp MQ, Morgan SS, Hager JA, Beliakoff J, Whitesell LJ, Bowden GT, Romagnolo DF: An estrogen receptor-alpha/p300 complex activates the BRCA-1 promoter at an AP-1 site that binds Jun/Fos transcription factors: repressive effects of $\mathrm{p} 53$ on BRCA-1 transcription Neoplasia 2005, 7:873-882.

18. Han WD, Si YL, Zhao YL, Li Q Wu ZQ Hao HJ, Song HJ: GC-rich promoter elements maximally confers estrogen-induced transactivation of LRP16 gene through ERa/Sp1 interaction in MCF-7 cells. J Steroid Biochem Mol Biol 2008, 109:47-56

19. Proietti CJ, Beguelin W, Flaque MC, Cayrol F, Rivas MA, Tkach M, Charreau EH, Schillaci R, Elizalde PV: Novel role of signal transducer and activator of transcription 3 as a progesterone receptor coactivator in breast cancer. Steroids 2011, 76:381-392.

20. Acconcia F, Kumar R: Signaling regulation of genomic and nongenomic functions of estrogen receptors. Cancer Lett 2006, 238:1-14.

21. O'Malley BW, Kumar R: Nuclear receptor coregulators in cancer biology. Cancer Res 2009, 69:8217-8222

22. Stanisic V, Lonard DM, O'Malley BW: Modulation of steroid hormone receptor activity. Prog Brain Res 2010, 181:153-176.

23. Nawaz Z, Lonard DM, Smith CL, Lev-Lehman E, Tsai SY, Tsai MJ, O'Malley BW: The Angelman syndrome-associated protein, E6-AP, is a coactivator for the nuclear hormone receptor superfamily. Mol Cell Biol 1999, 19:1182-1189.

24. Stanya KJ, Kao HY: New insights into the functions and regulation of the transcriptional corepressors SMRT and N-CoR. Cell Div 2009, 4:1-8.

25. Smith $\mathrm{CL}$, O'Malley BW: Coregulator function: a key to understanding tissue specificity of selective receptor modulators. Endocr Rev 2004, 25:45-71

26. Migliaccio A, Di Domenico M, Castoria G, de Falco A, Bontempo P, Nola E, Auricchio F: Tyrosine kinase/p21 ras/MAP-kinase pathway activation by estradiol-receptor complex in MCF-7 cells. EMBO J 1996, 15:1292-1300.

27. Migliaccio A, Piccolo D, Castoria G, Di Domenico M, Bilancio A, Lombardi M, Gong W, Beato M, Auricchio F: Activation of the Src/p21 ras/Erk pathway by progesterone receptor via cross-talk with estrogen receptor. EMBO J 1998, 17:2008-2018

28. Simoncini T, Hafezi-Moghadam A, Brazil DP, Ley K, Chin WW, Liao JK Interaction of oestrogen receptor with the regulatory subunit of phosphatidylinositol-3-OH kinase. Nature 2000, 407:538-541.

29. Castoria G, Migliaccio A, Bilancio A, Di Domenico M, de Falco A, Lombardi M, Fiorentino R, Varricchio L, Barone MV, Auricchio F: PI3-kinase in concert with Src promotes the S-phase entry of oestradiol-stimulated MCF-7 cells. EMBO / 2001, 20:6050-6059.

30. Castoria G, Barone MV, Di Domenico M, Bilancio A, Ametrano D, Migliaccio A, Auricchio F: Non-transcriptional action of oestradiol and progestin triggers DNA synthesis. EMBO J 1999, 18:2500-2510.

31. Lombardi M, Castoria G, Migliaccio A, Barone MV, Di Stasio R, Ciociola A, Bottero D, Yamaguchi H, Appella E, Auricchio F: Hormone-dependent nuclear export of estradiol receptor and DNA synthesis in breast cancer cells. J Cell Biol 2008, 182:327-340.

32. Boonyaratanakornkit V, Scott MP, Ribon V, Sherman L, Anderson SM, Maller JL, Miller WT, Edwards DP: Progesterone receptor contains a proline-rich motif that directly interacts with $\mathrm{SH} 3$ domains and activates c-Src family tyrosine kinases. Mol Cell 2001, 8:269-280

33. Faivre EJ, Lange CA: Progesterone receptors upregulate Wnt-1 to induce epidermal growth factor receptor transactivation and c-Src-dependent sustained activation of Erk1/2 mitogen-activated protein kinase in breast cancer cells. Mol Cell Biol 2007, 27:466-480

34. Lannigan DA: Estrogen receptor phosphorylation. Steroids 2003, 68:1-9.

35. Ward RD, Weigel NL: Steroid receptor phosphorylation: assigning function to site-specific phosphorylation. Biofactors 2009, 35:528-536.

36. Bunone G, Briand PA, Miksicek RJ, Picard D: Activation of the unliganded estrogen receptor by EGF involves the MAP kinase pathway and direct phosphorylation. EMBO J 1996, 15:2174-2183.

37. Joel PB, Traish AM, Lannigan DA: Estradiol-induced phosphorylation of serine 118 in the estrogen receptor is independent of p42/p44 mitogenactivated protein kinase. J Biol Chem 1998, 273:13317-13323.

38. Talukder AH, Li DQ, Manavathi B, Kumar R: Serine 28 phosphorylation of NRIF3 confers its co-activator function for estrogen receptor-alpha transactivation. Oncogene 2008, 27:5233-5242.

39. Zwart W, Griekspoor A, Berno V, Lakeman K, Jalink K, Mancini M, Neefjes J, Michalides R: PKA-induced resistance to tamoxifen is associated with an altered orientation of ERalpha towards co-activator SRC-1. EMBO J 2007 26:3534-3544.

40. Lee H, Bai W: Regulation of estrogen receptor nuclear export by ligandinduced and p38-mediated receptor phosphorylation. Mol Cell Biol 2002 22:5835-5845.

41. Arnold SF, Vorojeikina DP, Notides AC: Phosphorylation of tyrosine 537 on the human estrogen receptor is required for binding to an estrogen response element. J Biol Chem 1995, 270:30205-30212.

42. Fujimoto N, Katzenellenbogen BS: Alteration in the agonist/antagonist balance of antiestrogens by activation of protein kinase A signaling pathways in breast cancer cells: antiestrogen selectivity and promoter dependence. Mol Endocrinol 1994, 8:296-304.

43. Carascossa S, Dudek P, Cenni B, Briand PA, Picard D: CARM1 mediates the ligand-independent and tamoxifen-resistant activation of the estrogen receptor alpha by cAMP. Genes Dev 2010, 24:708-719.

44. Lange CA, Shen T, Horwitz KB: Phosphorylation of human progesterone receptors at serine- 294 by mitogen-activated protein kinase signals their degradation by the $26 \mathrm{~S}$ proteasome. Proc Natl Acad Sci U S A 2000 97:1032-1037.

45. Faivre EJ, Daniel AR, Hillard CJ, Lange CA: Progesterone receptor rapid signaling mediates serine 345 phosphorylation and tethering to specificity protein 1 transcription factors. Mol Endocrinol 2008, 22:823-837.

46. Proietti CJ, Rosemblit C, Beguelin W, Rivas MA, Diaz Flaque MC, Charreau EH, Schillaci R, Elizalde PV: Activation of Stat3 by heregulin/ErbB-2 through the co-option of progesterone receptor signaling drives breast cancer growth. Mol Cell Biol 2009, 29:1249-1265

47. Pierson-Mullany LK, Lange CA: Phosphorylation of progesterone receptor serine 400 mediates ligand-independent transcriptional activity in response to activation of cyclin-dependent protein kinase 2. Mol Cell Biol 2004, 24:10542-10557.

48. Cenni B, Picard D: Ligand-independent activation of steroid receptors: new roles for old players. Trends Endocrinol Metab 1999, 10:41-46.

49. Denner LA, Weigel NL, Maxwell BL, Schrader WT, O'Malley BW: Regulation of progesterone receptor-mediated transcription by phosphorylation. Science 1990, 250:1740-1743.

50. Power RF, Mani SK, Codina J, Conneely OM, O'Malley BW: Dopaminergic and ligand-independent activation of steroid hormone receptors. Science 1991, 254:1636-1639.

51. Ignar-Trowbridge DM, Nelson KG, Bidwell MC, Curtis SW, Washburn TF, McLachlan JA, Korach KS: Coupling of dual signaling pathways: epidermal growth factor action involves the estrogen receptor. Proc Natl Acad Sci U S A 1992, 89:4658-4662.

52. Hammes SR, Levin ER: Extranuclear steroid receptors: nature and actions. Endocr Rev 2007, 28:726-741.

53. Prossnitz ER, Arterburn JB, Smith HO, Oprea TI, Sklar LA, Hathaway HJ: Estrogen signaling through the transmembrane $\mathrm{G}$ protein-coupled receptor GPR30. Annu Rev Physiol 2008, 70:165-190.

54. Welboren WJ, Sweep FC, Span PN, Stunnenberg HG: Genomic actions of estrogen receptor alpha: what are the targets and how are they regulated? Endocr Relat Cancer 2009, 16:1073-1089.

55. Afhuppe W, Sommer A, Muller J, Schwede W, Fuhrmann U, Moller C: Global gene expression profiling of progesterone receptor modulators in T47D cells provides a new classification system. J Steroid Biochem Mol Biol 2009, 113:105-115.

56. Mrusek S, Classen-Linke I, Vloet A, Beier HM, Krusche CA: Estradiol and medroxyprogesterone acetate regulated genes in T47D breast cancer 
cells. Mol Cell Endocrinol 2005, 235:39-50.

57. Richer JK, Jacobsen BM, Manning NG, Abel MG, Wolf DM, Horwitz KB: Differential gene regulation by the two progesterone receptor isoforms in human breast cancer cells. J Biol Chem 2002, 277:5209-5218.

58. Martens JH, Rao NA, Stunnenberg HG: Genome-wide interplay of nuclear receptors with the epigenome. Biochim Biophys Acta 2010, 1812:818-823.

59. Lin CY, Vega VB, Thomsen JS, Zhang T, Kong SL, Xie M, Chiu KP, Lipovich L, Barnett DH, Stossi F, Yeo A, George J, Kuznetsov VA, Lee YK, Charn TH, Palanisamy N, Miller LD, Cheung E, Katzenellenbogen BS, Ruan Y, Bourque G, Wei CL, Liu ET: Whole-genome cartography of estrogen receptor alpha binding sites. PLOS Genet 2007, 3:e87.

60. Deome KB, Faulkin LJ, Jr, Bern HA, Blair PB: Development of mammary tumors from hyperplastic alveolar nodules transplanted into gland-free mammary fat pads of female C3H mice. Cancer Res 1959, 19:515-520.

61. Mallepell S, Krust A, Chambon P, Brisken C: Paracrine signaling through the epithelial estrogen receptor alpha is required for proliferation and morphogenesis in the mammary gland. Proc Natl Acad Sci U S A 2006, 103:2196-2201.

62. Brisken C, Park S, Vass T, Lydon JP, O'Malley BW, Weinberg RA: A paracrine role for the epithelial progesterone receptor in mammary gland development. Proc Natl Acad Sci U S A 1998, 95:5076-5081

63. Brisken C, Duss S: Stem cells and the stem cell niche in the breast: an integrated hormonal and developmental perspective. Stem Cell Rev 2007, 3:147-156.

64. Shoker BS, Jarvis C, Clarke RB, Anderson E, Hewlett J, Davies MP, Sibson DR, Sloane JP: Estrogen receptor-positive proliferating cells in the normal and precancerous breast. Am J Pathol 1999, 155:1811-1815.

65. Beleut M, Rajaram RD, Caikovski M, Ayyanan A, Germano D, Choi Y, Schneider $P$, Brisken C: Two distinct mechanisms underlie progesterone-induced proliferation in the mammary gland. Proc Natl Acad Sci U S A 2009, 107:2989-2994

66. Ewan KB, Oketch-Rabah HA, Ravani SA, Shyamala G, Moses HL, Barcellos-Hoff $\mathrm{MH}$ : Proliferation of estrogen receptor-alpha-positive mammary epithelial cells is restrained by transforming growth factor-beta1 in adult mice. Am J Pathol 2005, 167:409-417.

67. Luetteke NC, Qiu TH, Fenton SE, Troyer KL, Riedel RF, Chang A, Lee DC Targeted inactivation of the EGF and amphiregulin genes reveals distinct roles for EGF receptor ligands in mouse mammary gland development. Development 1999, 126:2739-2750.

68. Ciarloni L, Mallepell S, Brisken C: Amphiregulin is an essential mediator of estrogen receptor alpha function in mammary gland development. Proc Natl Acad Sci U S A 2007, 104:5455-5460.

69. Plowman GD, Green JM, McDonald VL, Neubauer MG, Disteche CM, Todaro GJ, Shoyab M: The amphiregulin gene encodes a novel epidermal growth factor-related protein with tumor-inhibitory activity. Mol Cell Biol 1990, 10:1969-1981

70. Sternlicht MD, Sunnarborg SW, Kouros-Mehr H, Yu Y, Lee DC, Werb Z: Mammary ductal morphogenesis requires paracrine activation of stromal EGFR via ADAM17-dependent shedding of epithelial amphiregulin. Development 2005, 132:3923-3933.

71. Sebastian J, Richards RG, Walker MP, Wiesen JF, Werb Z, Derynck R, Hom YK, Cunha GR, DiAugustine RP: Activation and function of the epidermal growth factor receptor and erbB-2 during mammary gland morphogenesis. Cell Growth Differ 1998, 9:777-785.

72. Wiesen JF, Young P, Werb Z, Cunha GR: Signaling through the stromal epidermal growth factor receptor is necessary for mammary ductal development. Development 1999, 126:335-344.

73. Richert MM, Wood TL: The insulin-like growth factors (IGF) and IGF type I receptor during postnatal growth of the murine mammary gland: sites of messenger ribonucleic acid expression and potential functions. Endocrinology 1999, 140:454-461.

74. Walden PD, Ruan W, Feldman M, Kleinberg DL: Evidence that the mammary fat pad mediates the action of growth hormone in mammary gland development. Endocrinology 1998, 139:659-662.

75. Li RW, Meyer MJ, Van Tassell CP, Sonstegard TS, Connor EE, Van Amburgh ME, Boisclair YR, Capuco AV: Identification of estrogen-responsive genes in the parenchyma and fat pad of the bovine mammary gland by microarray analysis. Physiol Genomics 2006, 27:42-53.

76. Peters K, Werner S, Liao X, Wert S, Whitsett J, Williams L: Targeted expression of a dominant negative FGF receptor blocks branching morphogenesis and epithelial differentiation of the mouse lung. EMBO J 1994,
13:3296-3301

77. Hoffman MP, Kidder BL, Steinberg ZL, Lakhani S, Ho S, Kleinman HK, Larsen M: Gene expression profiles of mouse submandibular gland development: FGFR1 regulates branching morphogenesis in vitro through BMP- and FGF-dependent mechanisms. Development 2002, 129:5767-5778.

78. Pedchenko VK, Imagawa W: Estrogen treatment in vivo increases keratinocyte growth factor expression in the mammary gland. J Endocrinol 2000, 165:39-49.

79. Lu P, Ewald AJ, Martin GR, Werb Z: Genetic mosaic analysis reveals FGF receptor 2 function in terminal end buds during mammary gland branching morphogenesis. Dev Biol 2008, 321:77-87.

80. Deroo BJ, Hewitt SC, Collins JB, Grissom SF, Hamilton KJ, Korach KS: Profile of estrogen-responsive genes in an estrogen-specific mammary gland outgrowth model. Mol Reprod Dev 2009, 76:733-750

81. Brisken C, Heineman A, Chavarria T, Elenbaas B, Tan J, Dey SK, McMahon JA, McMahon AP, Weinberg RA: Essential function of Wnt-4 in mammary gland development downstream of progesterone signaling. Genes Dev 2000, 14:650-654.

82. Boyle WJ, Simonet WS, Lacey DL: Osteoclast differentiation and activation. Nature 2003, 423:337-342.

83. Lacey DL, Timms E, Tan HL, Kelley MJ, Duns $\tan C R$, Burgess T, Elliott R, Colombero A, Elliott G, Scully S, Hsu H, Sullivan J, Hawkins N, Davy E, Capparelli C, Eli A, Qian YX, Kaufman S, Sarosi I, Shalhoub V, Senaldi G, Guo J, Delaney J, Boyle WJ: Osteoprotegerin ligand is a cytokine that regulates osteoclast differentiation and activation. Cell 1998, 93:165-176.

84. Fata JE, Kong YY, Li J, Sasaki T, Irie-Sasaki J, Moorehead RA, Elliott R, Scully S, Voura EB, Lacey DL, Boyle WJ, KhoKha R, Penninger JM: The osteoclast differentiation factor osteoprotegerin-ligand is essential for mammary gland development. Cell 2000, 103:41-50.

85. Brisken C, Ayyannan A, Nguyen C, Heineman A, Reinhardt F, Tan J, Dey SK, Dotto GP, Weinberg RA: IGF-2 is a mediator of prolactin-induced morphogenesis in the breast. Dev Cell 2002, 3:877-887.

86. Mulac-Jericevic B, Lydon JP, DeMayo FJ, Conneely OM: Defective mammary gland morphogenesis in mice lacking the progesterone receptor $B$ isoform. Proc Natl Acad SciU S A 2003, 100:9744-9749.

87. Fernandez-Valdivia R, Mukherjee A, Ying Y, Li J, Paquet M, DeMayo FJ, Lydon $J P$ : The RANKL signaling axis is sufficient to elicit ductal side-branching and alveologenesis in the mammary gland of the virgin mouse. Dev Biol 2009, 328:127-139

88. Mukherjee A, Soyal SM, Li J, Ying Y, He B, DeMayo FJ, Lydon JP: Targeting RANKL to a specific subset of murine mammary epithelial cells induces ordered branching morphogenesis and alveologenesis in the absence of progesterone receptor expression. FASEB J 2010, 24:4408-4419.

89. Copp DH, Cheney B: Calcitonin-a hormone from the parathyroid which lowers the calcium-level of the blood. Nature 1962, 193:381-382.

90. Ismail PM, DeMayo FJ, Amato P, Lydon JP: Progesterone induction of calcitonin expression in the murine mammary gland. J Endocrino/ 2004, 180:287-295.

91. Stingl J, Eirew P, Ricketson I, Shackleton M, Vaillant F, Choi D, Li HI, Eaves CJ: Purification and unique properties of mammary epithelial stem cells. Nature 2006, 439:993-997.

92. Shackleton M, Vaillant F, Simpson KJ, Stingl J, Smyth GK, Asselin-Labat ML, Wu L, Lindeman GJ, Visvader JE: Generation of a functional mammary gland from a single stem cell. Nature 2006, 439:84-88.

93. Asselin-Labat ML, Shackleton M, Stingl J, Vaillant F, Forrest NC, Eaves CJ, Visvader JE, Lindeman GJ: Steroid hormone receptor status of mouse mammary stem cells. J Natl Cancer Inst 2006, 98:1011-1014.

94. Tanos T, Brisken C: What signals operate in the mammary niche? Breast Dis 2008, 29:69-82

95. Joshi PA, Jackson HW, Beristain AG, Di Grappa MA, Mote PA, Clarke CL, Stingl J, Waterhouse PD, Khokha R: Progesterone induces adult mammary stem cell expansion. Nature 2010, 465:803-807.

96. Asselin-Labat ML, Vaillant F, Sheridan JM, Pal B, Wu D, Simpson ER, Yasuda H, Smyth GK, Martin TJ, Lindeman GJ, Visvader JE: Control of mammary stem cell function by steroid hormone signalling. Nature 2010, 465:798-802.

97. Van Keymeulen A, Rocha AS, Ousset M, Beck B, Bouvencourt G, Rock J, Sharma N, Dekoninck S, Blanpain C: Distinct stem cells contribute to mammary gland development and maintenance. Nature 2011, 479:189-193.

98. Prat A, Perou CM: Deconstructing the molecular portraits of breast cancer. Mol Oncol 2011, 5:5-23. 
99. West M, Blanchette C, Dressman H, Huang E, Ishida S, Spang R, Zuzan H, Olson JA, Jr, Marks JR, Nevins JR: Predicting the clinical status of human breast cancer by using gene expression profiles. Proc Natl Acad Sci U SA 2001, 98:11462-11467.

100. Gruvberger S, Ringner M, Chen Y, Panavally S, Saal LH, Borg A, Ferno M, Peterson C, Meltzer PS: Estrogen receptor status in breast cancer is associated with remarkably distinct gene expression patterns. Cancer Res 2001, 61:5979-5984

101. Dressman MA, Walz TM, Lavedan C, Barnes L, Buchholtz S, Kwon I, Ellis MJ, Polymeropoulos MH: Genes that co-cluster with estrogen receptor alpha in microarray analysis of breast biopsies. Pharmacogenomics J 2001, 1:135-141.

102. van't Veer LJ, Dai H, van de Vijver MJ, He YD, Hart AA, Mao M, Peterse HL, van der Kooy K, Marton MJ, Witteveen AT, Schreiber GJ, Kerkhoven RM, Roberts C, Linsley PS, Bernards R, Friend SH: Gene expression profiling predicts clinical outcome of breast cancer. Nature 2002, 415:530-536.

103. Sotiriou C, Neo SY, McShane LM, Korn EL, Long PM, Jazaeri A, Martiat P, Fox SB, Harris AL, Liu ET: Breast cancer classification and prognosis based on gene expression profiles from a population-based study. Proc Natl Acad Sci U S A 2003, 100:10393-10398.

104. Schneider J, Ruschhaupt M, Buness A, Asslaber M, Regitnig P, Zatloukal K, Schippinger W, Ploner F, Poustka A, Sultmann H: Identification and metaanalysis of a small gene expression signature for the diagnosis of estrogen receptor status in invasive ductal breast cancer. Int J Cancer 2006, 119:2974-2979.

105. Tozlu S, Girault I, Vacher S, Vendrell J, Andrieu C, Spyratos F, Cohen P, Lidereau $R$, Bieche I: Identification of novel genes that co-cluster with estrogen receptor alpha in breast tumor biopsy specimens, using a large-scale real-time reverse transcription-PCR approach. Endocr Relat Cancer 2006, 13:1109-1120

106. Wilson BJ, Giguere V: Meta-analysis of human cancer microarrays reveals GATA3 is integral to the estrogen receptor alpha pathway. Mol Cancer 2008, 7:49

107. Kouros-Mehr H, Slorach EM, Sternlicht MD, Werb Z: GATA-3 maintains the differentiation of the luminal cell fate in the mammary gland. Cell 2006 127:1041-1055.

108. Asselin-Labat ML, Sutherland KD, Barker H, Thomas R, Shackleton M, Forrest NC, Hartley L, Robb L, Grosveld FG, van der Wees J, Lindeman G and Visvade J: Gata-3 is an essential regulator of mammary-gland morphogenesis and luminal-cell differentiation. Nat Cell Biol 2007, 9:201-209.

109. Eeckhoute J, Keeton EK, Lupien M, Krum SA, Carroll JS, Brown M: Positive cross-regulatory loop ties GATA-3 to estrogen receptor alpha expression in breast cancer. Cancer Res 2007, 67:6477-6483.

110. Welboren WJ, van Driel MA, Janssen-Megens EM, van Heeringen SJ, Sweep FC, Span PN, Stunnenberg HG: ChIP-Seq of ERalpha and RNA polymerase II defines genes differentially responding to ligands. EMBO J 2009, 28:1418-1428

111. Grober OM, Mutarelli M, Giurato G, Ravo M, Cicatiello L, De Filippo MR, Ferraro L, Nassa G, Papa MF, Paris O, Tarallo R, Luo S, Schroth GP, Benes V, Weisz A: Global analysis of estrogen receptor beta binding to breast cancer cell genome reveals an extensive interplay with estrogen receptor alpha for target gene regulation. BMC Genomics, 2011, 12:36

112. Carroll JS, Meyer CA, Song J, Li W, Geistlinger TR, Eeckhoute J, Brodsky AS, Keeton EK, Fertuck KC, Hall GF, Wang Q, Bekiranov S, Sementchenko V, Fox EA, Silver PA, Gingeras TR, Liu XS, Brown M: Genome-wide analysis of estrogen receptor binding sites. Nat Genet 2006, 38:1289-1297.

113. Jin VX, Leu YW, Liyanarachchi S, Sun H, Fan M, Nephew KP, Huang TH, Davuluri $\mathrm{RV}$ : Identifying estrogen receptor alpha target genes using integrated computational genomics and chromatin immunoprecipitation microarray. Nucl Acids Res 2004, 32:6627-6635.

114. Kouros-Mehr H, Bechis SK, Slorach EM, Littlepage LE, Egeblad M, Ewald AJ, Pai SY, Ho IC, Werb Z: GATA-3 links tumor differentiation and dissemination in a luminal breast cancer model. Cancer Cell 2008, 13:141-152.

115. Fang SH, Chen Y, Weigel RJ: GATA-3 as a marker of hormone response in breast cancer. J Surg Res 2009, 157:290-295.

116. Yoon NK, Maresh EL, Shen D, Elshimali Y, Apple S, Horvath S, Mah V, Bose S, Chia D, Chang HR, Goodglick L: Higher levels of GATA3 predict better survival in women with breast cancer. Hum Pathol 2010, 41:1794-1801.

117. Badve S, Turbin D, Thorat MA, Morimiya A, Nielsen TO, Perou CM, Dunn S, Huntsman DG, Nakshatri H: FOXA1 expression in breast cancer - correlation with luminal subtype A and survival. Clin Cancer Res 2007, 13(15 Pt 1):4415-4421.
118. Bernardo GM, Lozada KL, Miedler JD, Harburg G, Hewitt SC, Mosley JD, Godwin AK, Korach KS, Visvader JE, Kaestner KH, Abdul-Karim FW, Montano MM, Keri RA: FOXA1 is an essential determinant of ERa expression and mammary ductal morphogenesis. Development 2010, 137:2045-2054.

119. Schuur ER, Loktev AV, Sharma M, Sun Z, Roth RA, Weigel RJ: Liganddependent interaction of estrogen receptor-alpha with members of the forkhead transcription factor family. J Biol Chem 2001, 276:33554-33560.

120. Carroll JS, Liu XS, Brodsky AS, Li W, Meyer CA, Szary AJ, Eeckhoute J, Shao W, Hestermann EV, Geistlinger TR, Fox, EA, Silver PA, Brown M: Chromosomewide mapping of estrogen receptor binding reveals long-range regulation requiring the forkhead protein FoxA1. Cell 2005, 122:33-43.

121. Carroll JS, Brown M: Estrogen receptor target gene: an evolving concept. Mol Endocrinol 2006, 20:1707-1714.

122. Laganiere J, Deblois G, Lefebvre C, Bataille AR, Robert F, Giguere V: From the Cover: Location analysis of estrogen receptor alpha target promoters reveals that FOXA1 defines a domain of the estrogen response. Proc Natl Acad SciU SA 2005, 102:11651-11656.

123. Hurtado A, Holmes KA, Ross-Innes CS, Schmidt D, Carroll JS: FOXA1 is a key determinant of estrogen receptor function and endocrine response. Nat Genet 2010, 43:27-33.

124. Hisamatsu Y, Tokunaga E, Yamashita N, Akiyoshi S, Okada S, Nakashima Y, Aishima S, Morita M, Kakeji Y, Maehara Y: Impact of FOXA1 expression on the prognosis of patients with hormone receptor-positive breast cancer. Ann Surg Oncol 2011, 19:1145-1152.

125. Albergaria A, Paredes J, Sousa B, Milanezi F, Carneiro V, Bastos J, Costa S, Vieira D, Lopes N, Lam EW, Lunet N, Schmitt F: Expression of FOXA1 and GATA-3 in breast cancer: the prognostic significance in hormone receptor-negative tumours. Breast Cancer Res 2009, 11:R40.

126. Usary J, Llaca V, Karaca G, Presswala S, Karaca M, He X, Langerod A, Karesen R, Oh DS, Dressler LG, Lonning PE, Strausberg RL, Chanock S, Borresen-Dale AL, Perou CM: Mutation of GATA3 in human breast tumors. Oncogene 2004, 23:7669-7678

127. Eeckhoute J, Carroll JS, Geistlinger TR, Torres-Arzayus MI, Brown M: A celltype-specific transcriptional network required for estrogen regulation of cyclin $D_{1}$ and cell cycle progression in breast cancer. Genes Dev 2006, 20:2513-2526.

128. Shoker BS, Jarvis C, Davies MP, Iqbal M, Sibson DR, Sloane JP: Immunodetectable cyclin $D_{1}$ is associated with oestrogen receptor but not Ki67 in normal, cancerous and precancerous breast lesions. Br J Cancer 2001, 84:1064-1069.

129. Oh YL, Choi JS, Song SY, Ko YH, Han BK, Nam SJ, Yang JH: Expression of p21Waf1, p27Kip1 and cyclin D1 proteins in breast ductal carcinoma in situ: relation with clinicopathologic characteristics and with $\mathrm{p} 53$ expression and estrogen receptor status. Pathol Int 2001, 51:94-99.

130. Roy PG, Pratt N, Purdie CA, Baker L, Ashfield A, Quinlan P, Thompson AM: High CCND1 amplification identifies a group of poor prognosis women with estrogen receptor positive breast cancer. Int J Cancer 2010, 127:355-360.

131. Kannan N, Kang J, Kong X, Tang J, Perry JK, Mohankumar KM, Miller LD, Liu ET, Mertani HC, Zhu T, Grandison PM Liu DX, Lobie PE: Trefoil factor 3 is oncogenic and mediates anti-estrogen resistance in human mammary carcinoma. Neoplasia 2010, 12:1041-1053.

132. Amiry N, Kong X, Muniraj N, Kannan N, Grandison PM, Lin J, Yang Y, Vouyovitch CM, Borges S, Perry JK, Mertani HC, Zhu T, Liu D, Lobie PE: Trefoil factor-1 (TFF1) enhances oncogenicity of mammary carcinoma cells. Endocrinology 2009, 150:4473-4483.

133. Lin CY, Strom A, Vega VB, Kong SL, Yeo AL, Thomsen JS, Chan WC, Doray B, Bangarusamy DK, Ramasamy A, Vergara LA, Tang S, Chong A, Bajic VB, Miler LD, Gustafsson J, Liu ET: Discovery of estrogen receptor alpha target genes and response elements in breast tumor cells. Genome Bio/ 2004, 5:R66.

134. Manning DL, Daly RJ, Lord PG, Kelly KF, Green CD: Effects of oestrogen on the expression of a $4.4 \mathrm{~kb}$ mRNA in the ZR-75-1 human breast cancer cell line. Mol Cell Endocrinol 1988, 59:205-212.

135. Taylor KM, Morgan HE, Smart K, Zahari NM, Pumford S, Ellis IO, Robertson JF, Nicholson RI: The emerging role of the LIV-1 subfamily of zinc transporters in breast cancer. Mol Med 2007, 13:396-406.

136. Bouras T, Southey MC, Chang AC, Reddel RR, Willhite D, Glynne R, Henderson MA, Armes JE, Venter DJ: Stanniocalcin 2 is an estrogen-responsive gene coexpressed with the estrogen receptor in human breast cancer. Cancer Res 2002, 62:1289-1295.

137. Kandouz M, Lombet A, Perrot JY, Jacob D, Carvajal S, Kazem A, Rostene W, Therwath A, Gompel A: Proapoptotic effects of antiestrogens, progestins 
and androgen in breast cancer cells. J Steroid Biochem Mol Bio/ 1999, 69:463-471.

138. Drabsch Y, Hugo H, Zhang R, Dowhan DH, Miao YR, Gewirtz AM, Barry SC, Ramsay RG, Gonda TJ: Mechanism of and requirement for estrogenregulated MYB expression in estrogen-receptor-positive breast cancer cells. Proc Natl Acad Sci U S A 2007, 104:13762-13767.

139. Gudas JM, Klein RC, Oka M, Cowan KH: Posttranscriptional regulation of the c-myb proto-oncogene in estrogen receptor-positive breast cancer cells. Clin Cancer Res 1995, 1:235-243.

140. Masiakowski P, Breathnach R, Bloch J, Gannon F, Krust A, Chambon P: Cloning of CDNA sequences of hormone-regulated genes from the MCF-7 human breast cancer cell line. Nucl Acids Res 1982, 10:7895-7903.

141. Oh DS, Troester MA, Usary J, Hu Z, He X, Fan C, Wu J, Carey LA, Perou CM: Estrogen-regulated genes predict survival in hormone receptor-positive breast cancers. J Clin Oncol 2006, 24:1656-1664.

142. Stender JD, Kim K, Charn TH, Komm B, Chang KC, Kraus WL, Benner C, Glass CK, Katzenellenbogen BS: Genome-wide analysis of estrogen receptor alpha DNA binding and tethering mechanisms identifies Runx 1 as a novel tethering factor in receptor-mediated transcriptional activation. Mol Cell Biol 2010, 30:3943-3955.

143. Ross-Innes CS, Stark R, Teschendorff AE, Holmes KA, Ali HR, Dunning MJ, Brown GD, Gojis O, Ellis IO, Green AR, Ali S, Chin SF, Palmieri C, Caldas C, Carroll JS: Differential oestrogen receptor binding is associated with clinical outcome in breast cancer. Nature 2010, 481:389-393.

144. Graham JD, Mote PA, Salagame U, van Dijk JH, Balleine RL, Huschtscha LI, Reddel RR, Clarke CL: DNA replication licensing and progenitor numbers are increased by progesterone in normal human breast. Endocrinology 2009, 150:3318-3326.

145. Ramamoorthy S, Dhananjayan SC, Demayo FJ, Nawaz Z: Isoform-specific degradation of PR-B by E6-AP is critical for normal mammary gland development. Mol Endocrinol 2010, 24:2099-2113.

146. Santini D, Perrone G, Roato I, Godio L, Pantano F, Grasso D, Russo A, Vincenzi B, Fratto ME, Sabbatini R, Della Pepa C, Porta C, Del Conte A, Schiavon G, Berruti A, Tomasino RM, Papotti M, Papapietro N, Onetti Muda A, Denaro V, Tonini G.: Expression pattern of receptor activator of NFKB (RANK) in a series of primary solid tumors and related bone metastases. J Cell Physiol 2010, 226:780-784

147. Gonzalez-Suarez E, Jacob AP, Jones J, Miller R, Roudier-Meyer MP, Erwert R, Pinkas J, Branstetter D, Dougall WC: RANK ligand mediates progestininduced mammary epithelial proliferation and carcinogenesis. Nature 2010, 468:103-107.
148. Lo PK, Mehrotra J, D'Costa A, Fackler MJ, Garrett-Mayer E, Argani P, Sukumar S: Epigenetic suppression of secreted frizzled related protein 1 (SFRP1) expression in human breast cancer. Cancer Biol Ther 2006, 5:281-286.

149. Veeck J, Noetzel E, Bektas N, Jost E, Hartmann A, Knuchel R, Dahl E: Promoter hypermethylation of the SFRP2 gene is a high-frequent alteration and tumor-specific epigenetic marker in human breast cancer. Mol Cancer 2008, 7:83.

150. Veeck J, Geisler C, Noetzel E, Alkaya S, Hartmann A, Knuchel R, Dahl E: Epigenetic inactivation of the secreted frizzled-related protein-5 (SFRP5) gene in human breast cancer is associated with unfavorable prognosis. Carcinogenesis 2008, 29:991-998.

151. Ai L, Tao Q, Zhong S, Fields CR, Kim WJ, Lee MW, Cui Y, Brown KD, Robertson KD: Inactivation of Wnt inhibitory factor-1 (WIF1) expression by epigenetic silencing is a common event in breast cancer. Carcinogenesis 2006, 27:1341-1348.

152. Suzuki H, Toyota M, Carraway H, Gabrielson E, Ohmura T, Fujikane T, Nishikawa N, Sogabe Y, Nojima M, Sonoda T, Mori M, Hirata K, Imai K, Shinomura Y, Baylin $S B$, Tokino T: Frequent epigenetic inactivation of Wnt antagonist genes in breast cancer. Br J Cancer 2008, 98:1147-1156.

153. Jin Z, Tamura G, Tsuchiya T, Sakata K, Kashiwaba M, Osakabe M, Motoyama T: Adenomatous polyposis coli (APC) gene promoter hypermethylation in primary breast cancers. Br J Cancer 2001, 85:69-73.

154. Virmani AK, Rathi A, Sathyanarayana UG, Padar A, Huang CX, Cunnigham HT, Farinas AJ, Milchgrub S, Euhus DM, Gilcrease M, Herman J, Minna JD, Gazdar AF: Aberrant methylation of the adenomatous polyposis coli (APC) gene promoter $1 \mathrm{~A}$ in breast and lung carcinomas. Clin Cancer Res 2001, 7:1998-2004.

155. Migliaccio A, Castoria G, Giovannelli P, Auricchio F: Cross talk between epidermal growth factor (EGF) receptor and extra nuclear steroid receptors in cell lines. Mol Cell Endocrinol 2010, 327:19-24.

156. Lee S, Medina D, Tsimelzon A, Mohsin SK, Mao S, Wu Y, Allred DC: Alterations of gene expression in the development of early hyperplastic precursors of breast cancer. Am J Pathol 2007, 171:252-262.

doi:10.1186/bcr3166

Cite this article as: Tanos T, et al.: ER and PR signaling nodes during mammary gland development. Breast Cancer Research 2012, 14:210. 